\title{
The Way to Improve Employees' Job Satisfaction in Korean Social Enterprises: The Moderating Effects of Person-Organization Fit, Person-Job Fit, and Person-Supervisor Fit
}

\author{
Xiu Jin ${ }^{1} \&$ Sang Woo Hahm ${ }^{1}$ \\ ${ }^{1}$ Department of Business Administration, Soongsil University, Seoul, South Korea \\ Correspondence: Sang Woo Hahm, Department of Business Administration, Soongsil University, Seoul, South \\ Korea.
}

Received: April 30, 2019

Accepted: May 30, 2019

Online Published: June 11, 2019

doi:10.5430/ijfr.v10n5p347

URL: https://doi.org/10.5430/ijfr.v10n5p347

\begin{abstract}
Human resources play a key role in achieving a high level of organizational performance and the importance is still emphasized in our society. Nonetheless, organizations are experiencing negative phenomena such as job exhaustion and turnover. One of the key factors that can reduce these negative factors is seen as job satisfaction. In this regard, this research is an empirical study that it focused on the improvement of job satisfaction among organizational members who work in Korean social enterprises. In order to improve their job satisfaction, we focused on organizational communication and verified its role and emphasized its importance through its influence on job satisfaction. To improve the effect of organizational communication, we verified the role of person-organizational fit, person-job fit, and person-supervisor fit. These three types of fit were identified as ways to increase the influence of organizational communication on job satisfaction. Therefore, we examined the moderating effect of these three types of fit on the relationship between organizational communication and job satisfaction. The empirical results showed that the higher the three types of fit, the greater the influence of organizational communication on job satisfaction. Furthermore, by comparing the impacts of the three types of fit on job satisfaction, we identified what is the most essential fit. Based on the results of empirical analysis, this research discussed practical implications for improving organizational member's job satisfaction in Korean social enterprises and provides future research plans for the performance of Korean social enterprises.
\end{abstract}

Keywords: organizational communication, job satisfaction, person-organization fit, person-job fit, person-supervisor fit

\section{Introduction}

According to intense competition among organizations, it is extremely important for them to be able to maintain skilled employees to keep a competitive advantage (Frank, Finnegan, \& Taylor, 2004; Son, Kim \& Kim, 2014; Smith, Oczkowski, \& Smith, 2008; Lyston, 2018). Organizations should recruit and retain dedicated members and lead them to be loyal to their organizations in the context of a human-centered social environment. In this regard, it is necessary to explore a way that contributes to keeping professional or skilled employees in relation to their work (Son, Kim, \& Kim, 2014). Thus, Tooksoon (2011) suggested that organizations should apply HRM practices in workplaces and that they need to pay more attention to employee's job satisfaction in order to decrease turnover and obtain organizational goals (Tooksoon, 2011; Khemili \& Belloumi 2018). Job satisfaction could buffer against negative effects such as occupational stress (Van Saane, Sluiter, Verbeek, \& Frings-Dresen, 2003), high turnover (Umrani, Mahmood \& Ahmed, 2016; Tooksoon, 2011), burnout (Jayaratne \& Chess, 1986), and it could also increase employee retention and working conditions (Cole, Panchanadeswaran, \& Daining, 2004). In addition, a high level of job satisfaction makes it easy to maintain employees, reduce turnover, and also reduce the recruitment cost of new employees (Neog \& Barua, 2014; Eketu, 2018). Therefore, job satisfaction can be considered a key factor for maintaining employees, and therefore organizations should improve their job satisfaction. One of the factors that enhance job satisfaction in this regard is organizational communication because effective organizational communication can increase job satisfaction in the supervisor and subordinate relationship, and it also can reduce conflict (Spence, 1978). In order to in improve the influence of organizational communication on job satisfaction, this study focuses on person-organization fit, person-job fit, and person-supervisor fit. Previous research showed that 
perceived person-organization fit was positively related to job satisfaction (Cable \& DeRue, 2002; Piasentin \& Chapman, 2007), person-job fit had a strong relationship with job satisfaction (Kristof-Brown, Zimmerman, \& Johnson, 2005), and person-supervisor fit was also positively related to job satisfaction (Kristof-Brown, Zimmerman, \& Johnson, 2005). We considered that the three types of fitness were expected to directly enhance job satisfaction through previous research. For improving the influence of organizational communication on job satisfaction, we examined the level of job satisfaction when organizational communication and three conformities interacted with each other and verified the moderating effects of the three types of fitness. We also provided what was the most influential fitness in the relationship between organizational communication and job satisfaction (Ali \& Haseeb, 2019). This research is an empirical study that focused on the employees who work in Korean social enterprises and provided an effective way to improve job satisfaction, based on theories and the results of empirical analysis. Finally, we discuss several important practical implications for Korean social enterprises and also a present research direction for the performance of Korean social enterprises.

\section{Literature review}

\subsection{Organizational Communication}

Communication is critical for all functions of organizations (Goris, 2007; Vafa,Sappington \& Coombs 2018). Not only business organizations, but also all organizations have communication needs and challenges (Baker, 2002). Organizational communication was defined as the degree of information related to a job that is conveyed among organizational members (Price, 1997). Communication is the foundation for facilitating greater interaction and cooperation among organizational members (Femi, 2014). The scholar suggested that good communication leads to motivating organizational members, reducing confusion, and helping to build genuine human relations. Furthermore, effective communication increases job satisfaction (Holtzhausen, 2002; Akhir, et.al 2018) and an employee's job performance (Goris, 2007). Contrary to this, poor organizational communication may lead to an employee's negative attitudes (Jiang \& Probst, 2014). Evidence has been demonstrated that poor organizational communication was related to higher turnovers, greater absenteeism, reduced production, and lower organizational commitment (Hargie, Dickson, \& Tourish, 1999). Thus, effective communication can convey the necessary information related to work among organizational members and it is expected to improve the technical skills of a job. Thus, organizational communication can be viewed as an integral part of the organization and its members.

\subsection{Job Satisfaction}

Job satisfaction as a topic has been paid considerable attention by researchers (Hayden \& Madsen, 2008; Ipole, Agba \& Okpa 2018). Job satisfaction was defined as workers' attitude toward their job, companies, coworkers, and psychological objects in their work environment (Beer, 1964). And Tooksoon (2011) suggested that job satisfaction refers to one's state-of-mind or feelings associated with the nature of their own work. Job satisfaction plays a key role for organizations and employees. The reason is that job satisfaction is important to the function of organizations (Ranz, Stueve, \& McQuistion, 2001), well-being (Curtis, 2007; Ranz, Stueve, \& McQuistion, 2001), productivity (Appelbaum, Bailey, Berg, \& Kalleberg, 2000; Gruneberg, 1979), and organizational profit (Gruneberg, 1979). In terms of employees, job satisfaction as a concept is a means of fulfilling people's job values such as job security and good wages (Hayden \& Madsen, 2008; Karl \& Sutton, 1998). Job satisfaction and dissatisfaction arise not from the nature of a job, but from the expectations and provisions of the job to an employee (Mahmoud, 2008; Neog \& Barua, 2014). According to Boselie \& van der Wiele (2002), a satisfied employee changes employers less and has fewer intentions to leave. Therefore, employees with a high level of job satisfaction are less likely to leave the organization. It suggests that a high level of job satisfaction is expected to be a key element in protecting human resources.

\subsection{Organizational Communication and Job Satisfaction}

In a workplace, communication openness has been suggested by organizational scholars as being a key factor in improving employee's job satisfaction (Walandari \& Burgess, 2011; Alfauzan \& Tarchouna 2017). Communication openness refers to employees in organizations willing to share their ideas and thoughts, even if those ideas go against popular opinion (Thomas, Zolin, \& Hartman, 2009). They suggested that if open communication is nonexistent or if organizational members cannot trust their supervisors, they will be more hesitant to engage in supporting organizational goals. Previous research (Bateman \& Strasser, 1984) has demonstrated that organizational commitment is positively related to job satisfaction. According to such process, it is expected that if communication in organizations is existent, employees will be more committed to the organization and this will lead to job satisfaction. And Klauss \& Bass (1982) also suggested that open communication predicts job satisfaction. The reason is that supervisors may be able to improve employees' job satisfaction by providing accurate and appropriate information for them (Jermsittiparsert, 2016; Pettit Jr, Goris, \& Vaught, 1997). They also suggested that individuals 
receiving correct, clear, and proper information may lead the individuals to perform appropriately, which in turn may lead to positive emotions about their jobs. Thus, effective organizational communication may improve job satisfaction. Based on these theories, we set the hypothesis as follows:

\section{H 1: Organizational communication will improve employees' job satisfaction.}

\subsection{Person-Organization Fit}

An organization tries to ensure the fit between the organizational members and the organizational system (Tyagi \& Gupta, 2005). Thus, the compatibility between the organizational members and the organization is a key variable for the organization. This variable may be regarded as personal-organization fit. Person-organization fit has been defined by Kristof as "the compatibility between people and organizations" (Kristof, 1996. p.4). According to this definition, the concept suggests that an individual's behaviors and attitudes are affected by the extent to which the organization and the individual have a fit on certain characteristics or the extent to which the organization and individual are similar (Silva, Hutcheson, \& Wahl, 2010). They emphasized that the greater the congruence or fit between the employee's ideal strategy and the organization's actual strategy, the higher the level of committed behavior to the organization will be demonstrated by organizational members. Furthermore, an individuals' perception of positive person-organization fit should lead to a high level of identification with the organization (Cable \& DeRue, 2002). It can be seen that positive person-organization fit may increase the sense of belonging to the organization. In this regard, a high sense of belonging to the organization is expected to reduce turnover intentions. Thus, person-organization fit will be expected to play a key role in maintaining human resources.

\subsection{Person-Job Fit}

Person-job fit is useful because some researchers have observed that employees' organizational commitment has decreased over recent years (Chhabra, 2015). Person-job fit is defined as the fit between individual characteristics (abilities, skills, and knowledge) and his or her job requirements, or the fit between a person's needs/desires and job attributes (Edwards, 1991). And it was also defined as "The extent to which the dispositions, abilities, expectations and performance contributions of an individual worker match the job demands, situational demands, expectations available and available rewards of a particular job" (Arora, 2000. p.326). Person-job fit can lead to high level of job satisfaction, organizational commitment, and a lower level of turnover intentions (Chhabra, 2015; Eboh, Abba \& Fatoye 2018). The scholar suggested poor person-job fit is directly and/or indirectly associated to greater turnover intentions and job dissatisfaction. Furthermore, person-job fit is a factor that can decrease job stress (Deniz, Noyan, \& Ertosun, 2015). According to these statements, it can be concluded that person-job fit is an important factor in reducing employees' turnover intention and increase their job satisfaction. In this regard, person-job fit is considered an extremely important factor for organizations because it is related to organizational performance.

\subsection{Person-Supervisor Fit}

Person-supervisor fit can be seen as a match between an employee's characteristics and their supervisor's characteristics (Van Vianen, 2018). The scholar suggested that supervisors are important for subordinates because subordinates can receive career opportunities and rewards from their supervisors. Person-supervisor fit is expected to play a positive role for employees and organizations. For example, person-supervisor fit helps build and protect diverse resources in organizations, retain employees, and it could be categorized as energy (Zhang, Ling, Zhang, \& Xie, 2015; Durak \& Çankaya 2018). In addition, the results of research by Zhang, Ling, Zhang, \& Xie (2015) showed that person-supervisor fit was positively related to organizational commitment, work engagement, and negatively related to turnover intention. In this regard, person-supervisor fit can be seen as an important factor in reducing turnover intention, promoting the relationship between subordinates and supervisor, and improving organizational performance. On the contrary, poor person-supervisor fit is expected to lead to greater turnover intention and lower organizational performance.

\subsection{Moderating Effects of Person-Organizational Fit, Person-Job Fit, Person-Supervisor Fit}

Theoretically, the relationship between attitudes and fit has been explained by saying that when the fit exists, the environment provides individuals with an opportunity to fulfill their needs (Arthur, Bell, Villado, \& Doverspike, 2006; Pervin, 1992; Rounds, Dawis, \& Lofquist, 1987; Schneider, Kristof-Brown, Goldstein, \& Smith, 1997). In this regard, fulfilling the needs of individuals leads to favorable attitudes such as organizational commitment and job satisfaction (Arthur, Bell, Villado, \& Doverspike, 2006). They suggested that social-psychological theories related to similarity in attitudes (Byrne, 1971; Newcomb, 1961) could also be used to express why the fit is recognized to be associated with favorable attitudes. In this context, individuals are willing to interact with other people who have similar psychological characteristics and the reason is that such interaction reinforces and verifies their own beliefs, 
affects, and expressed behaviors (Arthur, Bell, Villado, \& Doverspike, 2006; Swann, 1987; Swann, Stein-Seroussi, \& Giesler, 1992). In this regard, a high level of fit provides the opportunities for individuals to interact with similar people and results in favorable attitudes, such as organizational commitment and job satisfaction (Arthur, Bell, Villado, \& Doverspike, 2006). Based on these theories, it is expected that job satisfaction may be improved if organizational members fit with their organization, job, and supervisor.

In addition, the previous research by Klauss \& Bass (1982) and Walandari \& Burgess (2011) emphasized that organizational communication is considered as a predictor of job satisfaction. Therefore, smoother communication between organizational members and organizations, jobs and supervisors will enhance their job satisfaction.

Person-environment fit includes person-organization fit, person-job fit, and person-supervisor fit and so on (Redelinghuys \& Botha, 2016; Eketu, 2018). A central emphasis in almost every person-environment fit theory is that better fit can lead to superior outcomes, such as higher job satisfaction, better work adjustment, superior job performance, less stress, greater career success, and a larger likelihood to persist (Chatman, 1989; Dawis \& Lofquist, 1984; French, Caplan, \& Harrison, 1982; Holland, 1997; Su, Murdock, \& Rounds, 2015). Also, high person-environment fit alleviates an individual's worries about challenges and threats existing in their career environment (Gore \& Leuwerke 2000; Jiang, Hu, Wang, \& Jiang, 2017). Furthermore, Arthur, Bell, Villado, \& Doverspike (2006) emphasized that a high level of fit provides the opportunities for individuals to interact with similar people. Thus, it is more likely to activate communication between the organizational members with similar characteristics in the organization. Therefore, the higher the fitness of organizational members, the stronger is the influence of organizational communication on job satisfaction. Accordingly, we propose the following hypotheses:

H 2: Person-organization fit will improve job satisfaction.

H 3: Person-job fit will improve job satisfaction.

H 4: Person-supervisor fit will improve job satisfaction.

H5: Person-organization fit will moderate the relationship between organizational communication and job satisfaction.

H 6: Person-job fit will moderate the relationship between organizational communication and job satisfaction.

H7: Person-supervisor fit will moderate the relationship between organizational communication and job satisfaction.

\section{Methodology}

\subsection{Sample and Procedures}

The sample consisted of employees who work in a Korean social enterprise. The data for this research was collected during the summer of 2018. A total of 160 employees in a Korean social enterprise participated in this research. 16 questionnaires responded insincerely or inappropriately and were not selected. Finally, a total of 146 questionnaires were used in this research. The demographic characteristics of this study are as follows: 76 males $(52.1 \%)$ and 70 females (47.9\%) participated in the survey. In terms of age, $41(28.1 \%)$ were in their $20 \mathrm{~s}, 41(28.1 \%)$ were in their $30 \mathrm{~s}, 35(24.0 \%)$ were in their 40s, $29(19.8 \%)$ were over 50. In the regards to their company service, 33 (22.6\%) participants had worked between $1 \sim 2$ years at their current workplace, $30(20.5 \%)$ had worked between $2 \sim 3$ years, 17 (11.6\%) had worked for $3 \sim 4$ years, 32 (21.9\%) had worked between $4 \sim 5$ years, and 34 (23.4\%) had worked more than 5 years.

\subsection{Measures}

Organizational communication was assessed with nine items developed by Jiang \& Probst (2014). Sample items included "The lines of communication between management and employees are always open."

Person-organization fit was assessed with four items developed by Netemeyer, Boles, McKee, \& McMurrian (1997). Sample items included "I feel that my personal values are a good fit with this organization".

Person-job fit was assessed with five items developed by Lauver \& Kristof-Brown (2001). Sample items included "There is a good match between the requirements of this job and my skills".

Person-supervisor fit was assessed with five items developed by Chuang, Shen, \& Judge (2016). Sample items included "How would you describe the match between your work style and your supervisor's work style?"

In order to measure job satisfaction, this research used job satisfaction following Mossholder, Settoon, \& Henagan (2005) which included four items. Sample items included "All in all, I am satisfied with my job." 
In this research, all the items were measured by a seven point Likert-type scale. Scale anchors of all measurements ranged from 1 (completely disagree) to 7 (completely agree).

\section{Results}

First, a confirmatory factor analysis was performed. The results were as follows: For index, the results of an absolute fit index showed $X^{2}(p)=480.123(.000), X^{2} / \mathrm{df}=1.875$, RMSEA $=.078$, the incremental fit index was CFI $=.900$, IFI $=.902$, and the parsimonious fit index was PNFI $=.692$, PGFI $=.626$. These results show an acceptable fit according to Osman, Purwana, \& Saptono (2017). Therefore, it can be seen that the validity of the measurement items was acceptable. The average variance extraction of all variables were higher than 0.5 (organizational communication $=.535$, person-organization fit $=.638$, person-job fit $=.531$, person-supervisor fit $=.557$, and job satisfaction $=.584$ ) . The composite reliability of all variables were higher than 0.7 (organizational communication $=.830$, person-organization fit $=.721$, person-job fit $=.788$, person-supervisor fit $=.760$, and job satisfaction $=.774$ ). These results show an acceptable fit according to Lee, Cheung, \& Chen (2005). Hence, the results of all indexes were acceptable. In addition, all measurements have significant validity. Table 1 displays the results of goodness fit model.

Table 1. Results of the goodness of fit model

\begin{tabular}{lll}
\hline & AVE & C.R \\
\hline Organizational communication & .535 & .830 \\
\hline person-organization fit & .638 & .721 \\
\hline person-job fit & .531 & .788 \\
\hline person-supervisor fit & .557 & .760 \\
\hline job satisfaction & .584 & .774 \\
\hline Absolute fit indexes & $X^{2}(p)=480.123(.000), X^{2} / \mathrm{df}=1.875$, RMSEA $=.078$ \\
\hline Incremental fit indexes & $\mathrm{CFI}=.900$, IFI $=.902$, \\
\hline Parsimony adjusted indexes & PNFI $=.692$, PGFI $=.626$. \\
\hline
\end{tabular}

Second, the results of correlations, reliability, standard deviations, and means analysis are shown in Table 2. All values of Cronbach's Alpha were above .70 (organizational communication $=.908$, person-organization fit $=.836$, person-job fit $=.824$, person-supervisor fit $=.878$, and job satisfaction $=.843$.). Therefore, the Cronbach's Alpha values of this research satisfy the acceptable values suggested by Nunnally (1978). This means that the results show high reliability. Also, the results of correlation analysis showed as follows: Organizational communication ( $r=.753$, $p<.001)$ was positively associated with job satisfaction, Person-organization fit $(r=.656, p<.001)$, person-job fit $(r=.422, p<.001)$, and person-supervisor fit $(r=.722, p<.001)$. Person-organization fit $(r=.646, p<.001)$, person-job fit $(r=.505, p<.001)$, and person-supervisor fit $(r=.733, p<.001)$ were all positively associated with job satisfaction.

Table 2. The descriptive statistics, reliability, and correlation analysis

\begin{tabular}{|c|c|c|c|c|c|c|c|c|}
\hline & $\begin{array}{l}\text { Cronbach's } \\
\text { Alpha }\end{array}$ & Mean & $\begin{array}{l}\text { Std. } \\
\text { Deviation }\end{array}$ & 1 & 2 & 3 & 4 & 5 \\
\hline 1 & .908 & 4.687 & 1.093 & - & & & & \\
\hline 2 & .836 & 4.619 & 1.237 & $.656^{* * *}$ & - & & & \\
\hline 3 & .824 & 5.073 & .890 & $.422^{* * *}$ & $.491^{\text {*** }}$ & - & & \\
\hline 4 & .878 & 4.532 & 1.188 & $.722^{* * *}$ & $.615^{* * *}$ & $.443^{* * *}$ & - & \\
\hline 5 & .843 & 4.820 & 1.061 & $.753^{* * *}$ & $.646^{* * * *}$ & $.505^{* * *}$ & $.733^{* * *}$ & - \\
\hline
\end{tabular}

1=organizational communication, 2=person-organization fit, 3=person-job fit, 4=person-supervisor fit, 5=job satisfaction.

$* * *=p<.001 * *=p<.01 *=p<.05$ 
Table 3 displays the moderating effect of person-organization fit on the relationship between organizational communication and job satisfaction. Step 1 shows that organizational communication $(\beta=.753, p<.001)$ had a positive influence on job satisfaction. Thus, H1 was accepted. The step 2 shows that person- organization fit $(\beta=.267$, $p<.001)$ had a positive influence on job satisfaction. Thus, H2 was accepted. And step 3 shows that person-organization fit $(\beta=.125, p<.05)$ positively moderated the relationship between organizational communication and job satisfaction. Thus, H5 was accepted. Figure 1 displays the graph of moderating effect for person-organization fit. It shows that job satisfaction increases when organizational members experience higher levels of organizational communication. Job satisfaction is increased when organizational members have higher person-organization fit rather than having lower person-organization fit.

Table 3. The moderating effect of person-organizational fit

\begin{tabular}{|c|c|c|c|c|c|c|c|}
\hline \multicolumn{8}{|c|}{ Dependent variable: Job satisfaction } \\
\hline & \multicolumn{2}{|l|}{ step 1} & \multicolumn{2}{|l|}{ step 2} & \multicolumn{3}{|l|}{ step 3} \\
\hline & $\beta$ & $\mathrm{t}$ & $\beta$ & $\mathrm{t}$ & $\beta$ & $\mathrm{t}$ & VIF \\
\hline $\begin{array}{l}\text { Organizational } \\
\text { communication }\end{array}$ & $.753 * * *$ & 13.714 & $.577 * * *$ & 8.315 & $.589 * * *$ & 8.601 & 1.764 \\
\hline Person-organizational fit & & & $.267 * * *$ & 3.854 & $.285^{* * *}$ & 4.143 & 1.774 \\
\hline Interaction & & & & & $.125^{*}$ & 2.358 & 1.049 \\
\hline R2 (Adjusted R2) & \multicolumn{2}{|l|}{$.566(.563)$} & \multicolumn{2}{|l|}{$.607(.602)$} & \multicolumn{3}{|l|}{$.622(.614)$} \\
\hline$\triangle \mathrm{R} 2(\triangle$ Adjusted $\mathrm{R} 2)$ & \multicolumn{2}{|l|}{ - } & \multicolumn{2}{|l|}{.041 (.039) } & \multicolumn{3}{|l|}{$.015(.012)$} \\
\hline $\mathrm{F}$ & \multicolumn{2}{|l|}{$188.083 * * *$} & \multicolumn{2}{|l|}{$110.512 * * *$} & \multicolumn{3}{|l|}{$77.878^{* * *}$} \\
\hline
\end{tabular}

$* * *=p<.001 * *=p<.01 *=p<.05$

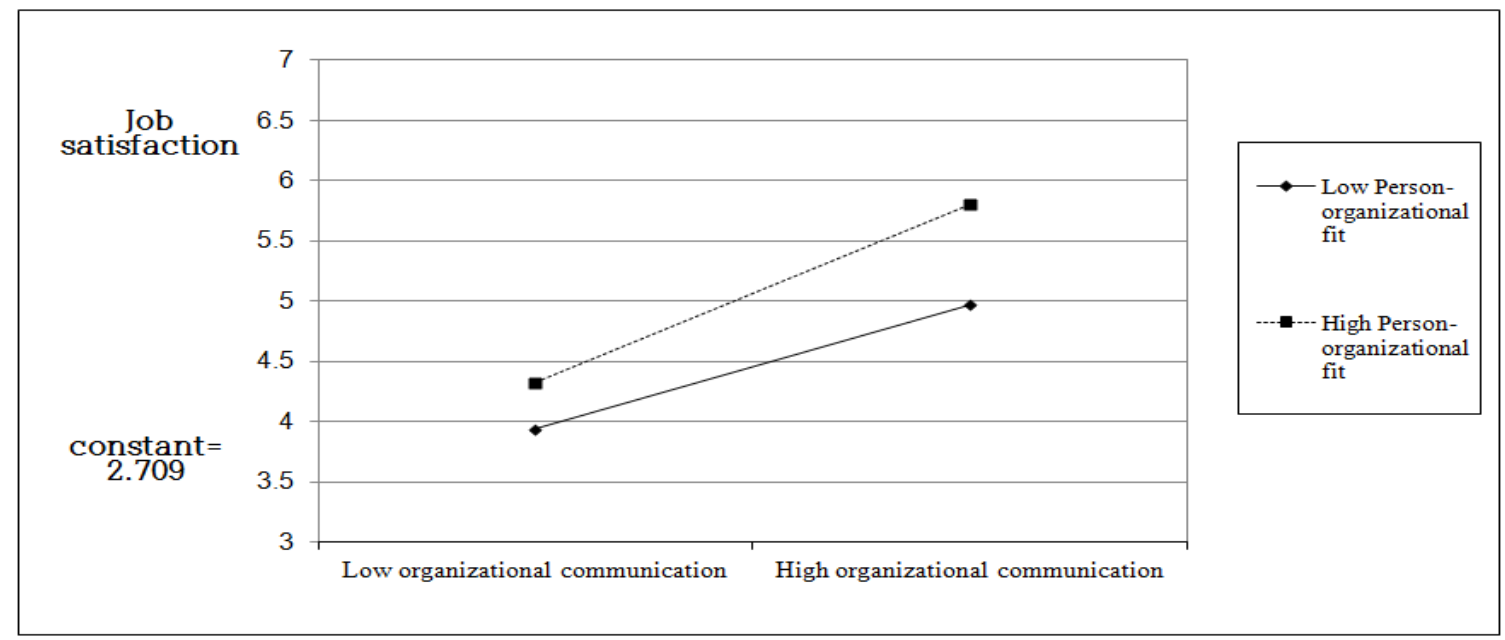

Figure 1. The graph of moderating effect for person-organizational fit

Table 4 displays the moderating effect of person-job fit on the relationship between organizational communication and job satisfaction. The step 2 shows that person-job fit $(\beta=.228, p<.001)$ had a positive influence on job satisfaction. Thus, H3 was accepted. Step 3 shows that person-job fit $(\beta=.163, p<.01)$ positively moderated the relationship between organizational communication and job satisfaction. Thus, H6 was accepted. Figure 2 displays the graph of moderating effect for person-job fit. It shows that job satisfaction increases when organizational members experience higher levels of organizational communication. Job satisfaction is increased more when organizational members have higher person-job fit rather than when they have lower person-job fit. 
Table 4. The moderating effect of person-job fit

Dependent variable: Job satisfaction

\begin{tabular}{|c|c|c|c|c|c|c|c|}
\hline & \multicolumn{2}{|l|}{ step 1} & \multicolumn{2}{|l|}{ step 2} & \multicolumn{3}{|l|}{ step 3} \\
\hline & $\beta$ & $\mathrm{t}$ & $\beta$ & $\mathrm{t}$ & $\beta$ & $\mathrm{t}$ & VIF \\
\hline $\begin{array}{l}\text { Organizational } \\
\text { communication }\end{array}$ & $.753 * * *$ & 13.714 & $.656 * * *$ & 11.377 & $.594 * * *$ & 9.917 & 1.385 \\
\hline Person-job fit & & & $.228 * * *$ & 3.949 & $.270 * * *$ & 4.658 & 1.293 \\
\hline Interaction & & & & & $.163 * *$ & 2.985 & 1.148 \\
\hline R2 (Adjusted R2) & $.566(.563)$ & & $.609(.6$ & & $.632(.62$ & & \\
\hline$\triangle \mathrm{R} 2(\Delta$ Adjusted R2) & - & & $.043(.0$ & & $.023(.02$ & & \\
\hline $\mathrm{F}$ & $188.083 * * *$ & & 111.368 & & $81.321 *$ & & \\
\hline
\end{tabular}

$* * *=p<.001 * *=p<.01 *=p<.05$

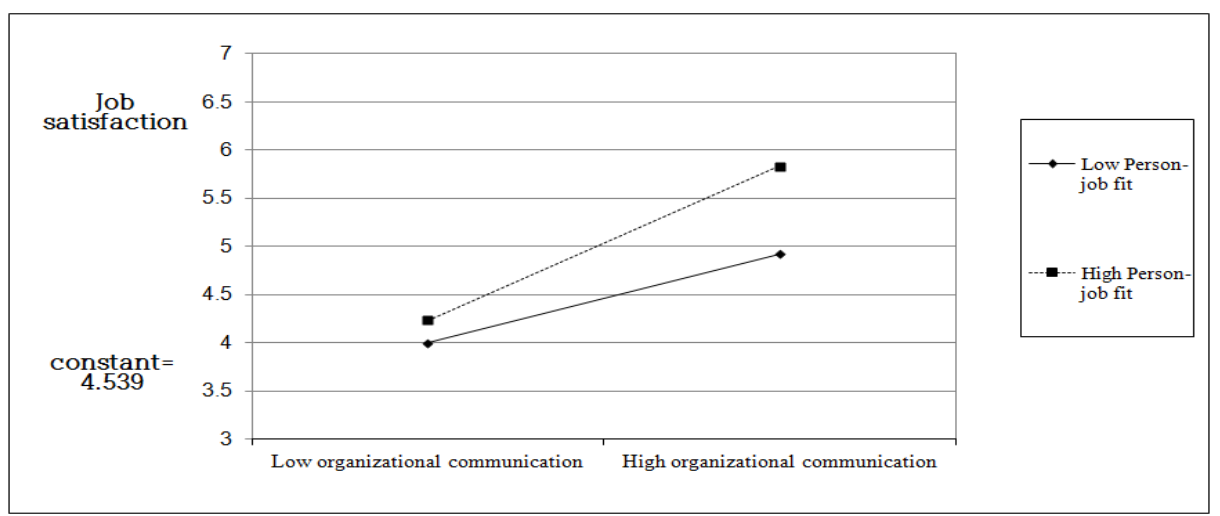

Figure 2. The graph of moderating effect for person-job fit

Table 5 displays the moderating effect of person-supervisor fit on the relationship between organizational communication and job satisfaction. Step 2 shows that person-supervisor fit $(\beta=.397, p<.001)$ had a positive influence on job satisfaction. Thus, H4 was accepted. Step 3 shows that person-supervisor fit $(\beta=.111, p<.05)$ positively moderated the relationship between organizational communication and job satisfaction. Thus, H7 was accepted. Figure 3 displays the graph of moderating effect for person- supervisor fit. It shows that job satisfaction increased when organizational members experienced higher levels of organizational communication. Job satisfaction is increased more when organizational members have higher person- supervisor fit rather than they have lower person-job fit.

Table 5. The moderating effect of person-supervisor fit

Dependent variable: Job satisfaction

\begin{tabular}{llllllll}
\hline & \multicolumn{2}{l}{ step 1 } & & step 2 & & step 3 & \\
\cline { 2 - 7 } & $\beta$ & $\mathrm{t}$ & $\beta$ & $\mathrm{t}$ & $\beta$ & $\mathrm{t}$ & $\mathrm{VIF}$ \\
\hline $\begin{array}{l}\text { Organizational } \\
\text { communication }\end{array}$ & $.753^{* * *}$ & 13.714 & $.466^{* * *}$ & 6.438 & $.460 * * *$ & 6.431 & 2.094 \\
\hline
\end{tabular}




\begin{tabular}{lccccc}
\hline Person-supervisor fit & $.397 * * *$ & 5.479 & $.429 * * *$ & 5.875 & 2.183 \\
\hline Interaction & & $.111^{*}$ & 2.162 & 1.071 \\
\hline $\mathrm{R} 2$ (Adjusted R2) & $.566(.563)$ & $.642(.637)$ & $.653(.646)$ & \\
\hline$\Delta \mathrm{R} 2(\triangle$ Adjusted R2) & & $.076(.074)$ & $.011(.009)$ & \\
\hline $\mathrm{F}$ & $188.083 * * *$ & $128.004 * * *$ & $89.087 * * *$ & \\
\hline$* * *=p<.001 * *=p<.01 *=p<.05$ & & &
\end{tabular}

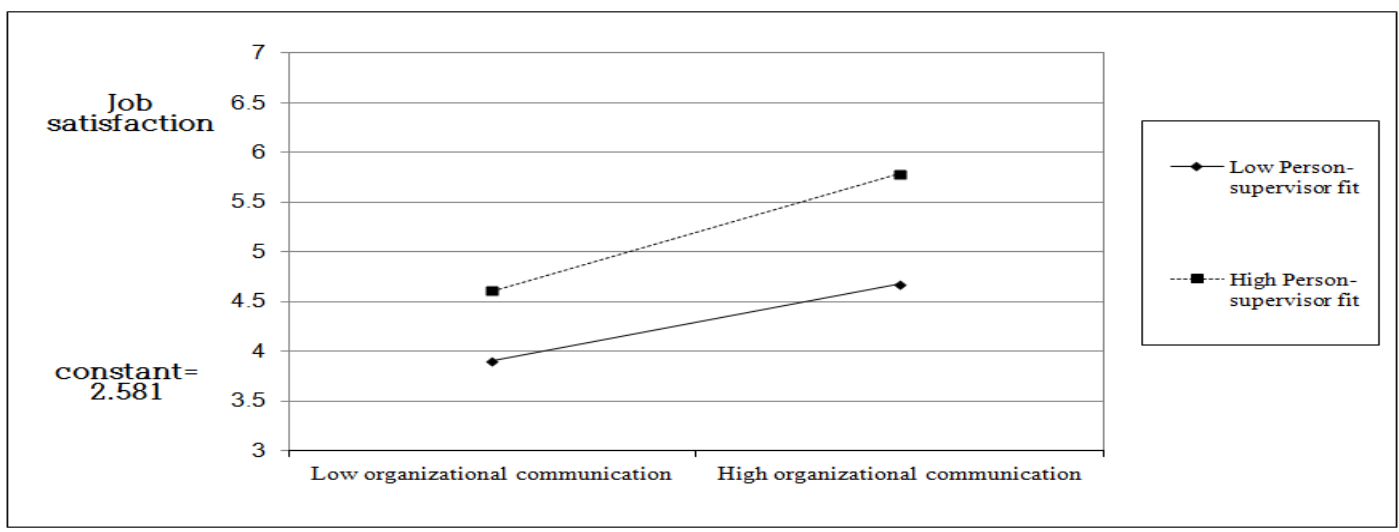

Figure 3. The graph of moderating effect for person-supervisor fit

\section{Discussion}

\subsection{Conclusion and Research Implications}

The purpose of this research is to improve organizational members' job satisfaction among Korean social enterprises. Thus, the relationship of organizational communication to job satisfaction was identified and its influence was also verified. According to empirical analysis, it was proven that organizational communication is a factor that can improve job satisfaction. Therefore, the study implies that communication among organizational members, communication between organizational members and supervisors, and communication between organizational members and organizations should be well-provided, and efforts should be made to ensure that communication is well developed in Korean social enterprises. In order to increase the impact of organizational communication on job satisfaction, we focused on person-organization fit, person-job fit, and person-supervisor fit and verified their roles and influence. As the results of the empirical analysis show, all of the types of fitness were found to positively moderate the relationship between organizational communication and job satisfaction. In this regard, the moderating effect of person-job fit was the strongest among them. Therefore, it suggests that all types of fitness are important for Korean social enterprises. Although previous studies on fitness have addressed its importance, this study emphasizes the importance of fitness and communication for workers in social enterprises. In Korean social enterprises, members should be motivated or trained to utilize the various skills they have and to use them in their work. In addition, it is necessary to build an effective relationship between the organizational members and supervisors. Furthermore, Korean social enterprise needs efforts to care for the needs and interests of its organizational members.

\subsection{Limitations and Future Directions}

The present research has some limitations that should be noted for future directions. First, this research focused on organizational communication as an independent variable to improve job satisfaction. In future research, empirical studies should be conducted to examine the positive factors that enhance job satisfaction and the negative factors that reduce job satisfaction, and verify their influence. Second, this research focused on the moderating effects of person-organization fit, person-job fit, and person-supervisor fit as the ways to improve job satisfaction. Thus, studies should be conducted to clarify the mediator variables that can reveal the key causes of job satisfaction in future studies. Third, in general, there have been a number of studies on job satisfaction as the outcome variable. Future research should focus on performance variables that can be expressed through job satisfaction. 


\section{References}

Akhir, R. M., Ahmad, S. N. B., Ahmad, H., \& Hashim, N. A. (2018). Staying or Leaving? The Influence of Employees' Engagement towards Turnover Decision Among Employees of A Semi-Government Organization in Malaysia. Humanities, 3(1), 55-62. https://doi.org/10.20448/801.31.55.62

Alfauzan, A. A., \& Tarchouna, N. (2017). The Role of an Aligned Curriculum Design in the Achievement of Learning Outcomes. Journal of Education and e-Learning Research, 4(3), 81-91. https://doi.org/10.20448/journal.509.2017.43.81.91

Ali, A., \& Haseeb, M. (2019). Radio frequency identification (RFID) technology as a strategic tool towards higher performance of supply chain operations in textile and apparel industry of Malaysia. Uncertain Supply Chain Management, 7(2), 215-226. https://doi.org/10.5267/j.uscm.2018.10.004

Appelbaum, E., T. Bailey, P. Berg., \& A. L. Kalleberg. (2000). Manufacturing advantage. Ithaca, NY: Cornell University Press.

Arora, R. (2000). Encyclopaedic dictionary of organization behaviour. Sarup \& Sons.

Arthur, J. W., Bell, S. T., Villado, A. J., \& Doverspike, D. (2006). The use of person-organization fit in employment decision making: an assessment of its criterion-related validity. The Journal of Applied Psychology, 91(4), 786-801. https://doi.org/10.1037/0021-9010.91.4.786

Baker, K. A. (2002). Organizational communication.

Bateman, T. S., \& Strasser, S. (1984). A longitudinal analysis of the antecedents of organizational commitment. Academy of Management Journal, 27(1), 95-112. https://doi.org/10.2307/255959

Beer, M. (1964). Organizational size and job satisfaction. Academy of Management Journal, 7(1), 34-44. https://doi.org/10.2307/255232

Boselie, P., \& van der Wiele, T. (2002). Employee perceptions of HRM and TQM, and the effects on satisfaction and intention to leave. Managing Service Quality: An International Journal, 12(3), 165-172. https://doi.org/10.1108/09604520210429231

Byrne, D. (1971). The attraction paradigm. New York: Academic Press.

Cable, D. M., \& DeRue, D. S. (2002). The convergent and discriminant validity of subjective fit perceptions. Journal of Applied Psychology, 87(5), 875-884. https://doi.org/10.1037/0021-9010.87.5.875

Chatman, J. A. (1989). Improving interactional organizational research: A model of person-organization fit. Academy of management Review, 14(3), 333-349. https://doi.org/10.5465/amr.1989.4279063

Chhabra, B. (2015). Person-job fit: mediating role of job satisfaction \& organizational commitment. Indian Journal of Industrial Relations, 50(4), 638-652.

Chuang, A., Shen, C. T., \& Judge, T. A. (2016). Development of a Multidimensional Instrument of P erson-E nvironment F it: The Perceived Person-Environment Fit Scale (PPEFS). Applied Psychology, 65(1), 66-98. https://doi.org/10.1111/apps.12036

Cole, D., Panchanadeswaran, S., \& Daining, C. (2004). Predictors of job satisfaction of licensed social workers: Perceived efficacy as a mediator of the relationship between workload and job satisfaction. Journal of Social Service Research, 31(1), 1-12. https://doi.org/10.1300/J079v31n01_01

Curtis, E. A. (2007). Job satisfaction: a survey of nurses in the Republic of Ireland. International Nursing Review, 54(1), 92-99. https://doi.org/10.1111/j.1466-7657.2007.00507.x

Dawis, R. V., \& Lofquist, L. H. (1984). A psychological theory of work adjustment. Minneapolis: University of Minnesota Press.

Deniz, N., Noyan, A., \& Ertosun, Ö. G. (2015). Linking person-job fit to job stress: The mediating effect of perceived person-organization fit. Procedia-Social and Behavioral Sciences, 207, 369-376. https://doi.org/10.1016/j.sbspro.2015.10.107

Durak, G., \& Çankaya, S. (2018). Seamless Learning: A Scoping Systematic Review Study. Journal of Education and E-Learning Research, 5(4), 225-234. https://doi.org/10.20448/journal.509.2018.54.225.234 
Eboh, A., Abba, J. Y., \& Fatoye, H. A. (2018). Impact Assessment of the Public Health Expenditure on the Health Outcome in Nigeria. International Journal of Social and Administrative Sciences, 3(2), 62-72. https://doi.org/10.18488/journal.136.2018.32.62.72

Edwards, J. R. (1991). Person-job fit: A conceptual integration, literature review, and methodological critique. In C. L. Cooper \& I. T. Robertson (Eds.), International Review of Industrial and Organizational Psychology (Vol. 6, pp. 283-357). Wiley, New York.

Eketu, C. A. (2018). Perspectives on Human Nature and Implications for Research in the Behavioural Sciences. International Journal of Emerging Trends in Social Sciences, 4(1), 42-46. https://doi.org/10.20448/2001.41.42.46

Femi, A. F. (2014). The impact of communication on workers' performance in selected organisations in Lagos State, Nigeria. IOSR Journal of Humanities And Social Science (IOSR-JHSS), 19(8), 75-82. https://doi.org/10.9790/0837-19827582

Frank, F. D., Finnegan, R. P., \& Taylor, C. R. (2004). The race for talent: Retaining and engaging workers in the $21 \mathrm{st}$ century. Human Resource Planning, 27(3), 12-25.

French, J. R. P., Jr., Caplan, R. D., \& Harrison, R. V. (1982). The mechanisms of job stress and strain. New York, NY: Wiley.

Gore, P. A., \& Leuwerke, W. C. (2000). Predicting occupational considerations: A comparison of selfefficacy beliefs, outcome expectations, and person-environment congruence. Journal of Career Assessment, 8(3), 237-250. https://doi.org/10.1177/106907270000800303

Goris, J. R. (2007). Effects of satisfaction with communication on the relationship between individual-job congruence and job performance/satisfaction. Journal of Management Development, 26(8), 737-752. https://doi.org/10.1108/02621710710777255

Gruneberg, M. M. (1979). Understanding job satisfaction. The Macmillan Press Ltd, London. https://doi.org/10.1007/978-1-349-03952-4

Hargie, O., Dickson, D., \& Tourish, D. (1999). Communication in management. Gower Publishing, Ltd.

Hayden, J., \& Madsen, S. (2008). The Influence of Value Perspectives on Prior Plans, Job Satisfaction, and Turnover Intentions in Nonprofit Agencies. Journal of Business Inquiry: Research, Education \& Application, 7(1), 33-40.

Holland, J. L. (1997). Making vocational choices: A theory of vocational personalities and work environments (3rd ed.). Odessa, FL: Psychological Assessment Resources.

Holtzhausen, D. (2002). The effects of a divisionalised and decentralised organisational structure on a formal internal communication function in a South African organisation. Journal of Communication Management, 6(4), 323-339. https://doi.org/10.1108/13632540210807152

Ipole, P. A., Agba, A. O., \& Okpa, J. T. (2018). Existing working conditions and labour unions agitations in cross river state civil service, Nigeria. Global Journal of Social Sciences Studies, 4(1), 39-51. https://doi.org/10.20448/807.4.1.39.51

Jayaratne, S., \& Chess, W. A. (1986). Job satisfaction: A comparison of caseworkers and administrators. Social Work, 31(2), 144-46. https://doi.org/10.1093/sw/31.2.144

Jermsittiparsert, K. (2016). Culture of 'Elephant front legs-hind legs': A debate on the actuality of sexual politics in Thai society. The Social Sciences, 11(1), 20-28.

Jiang, L., \& Probst, T. M. (2014). Organizational communication: A buffer in times of job insecurity?. Economic and Industrial Democracy, 35(3), 557-579. https://doi.org/10.1177/0143831X13489356

Jiang, Z., Hu, X., Wang, Z., \& Jiang, X. (2017). Career decision self-efficacy and life satisfaction in China: An empirical analysis. Social Indicators Research, 132(1), 137-154. https://doi.org/10.1007/s11205-015-1201-5

Karl, K. A., \& Sutton, C. L. (1998). Job values in today's workforce: A comparison of public and private sector employees. Public Personnel Management, 27(4), 515-527. https://doi.org/10.1177/009102609802700406

Khemili, H., \& Belloumi, M. (2018). Cointegration Relationship between Growth, Inequality and Poverty In Tunisia. International Journal of Applied Economics, Finance and Accounting, 2(1), 8-18. https://doi.org/10.33094/8.2017.2018.21.8.18 
Klauss, R., \& Bass, B. M. (1982), Interpersonal communication in organizations, New York, Academic Press.

Kristof, A. L. (1996). Person-organization fit: An integrative review of its conceptualizations, measurement, and implications. Personnel Psychology, 49(1), 1-49. https://doi.org/10.1111/j.1744-6570.1996.tb01790.x

Kristof-Brown, A. L., Zimmerman, R. D., \& Johnson, E. C. (2005). Consequences of individual's fit at work: A meta-analysis of person-job, person-organization, person-group, and person-supervisor fit. Personnel Psychology, 58(2), 281-342. https://doi.org/10.1111/j.1744-6570.2005.00672.x

Lauver, K. J., \& Kristof-Brown, A. (2001). Distinguishing between employees' perceptions of person-job and person-organization fit. Journal of Vocational Behavior, 59(3), 454-470. https://doi.org/10.1006/jvbe.2001.1807

Lee, M. K, Cheung, C. M., \& Chen, Z. (2005). Acceptance of Internet-based learning medium: the role of extrinsic and intrinsic motivation. Information \& Management, 42(8), 1095-1104. https://doi.org/10.1016/j.im.2003.10.007

Lyston, T. (2018). Restoration for State's Financial Loss as a Countermeasure against Corruption in Indonesia. International Journal of Social Sciences Perspectives, 2(2), 161-164. https://doi.org/10.33094/7.2017.2018.22.161.164

Mahmoud, A. H. (2008). A study of nurses' job satisfaction: the relationship to organizational commitment, perceived organizational support, transactional leadership, transformational leadership, and level of education. European Journal of Scientific Research, 22(2), 286-295.

Mossholder, K. W., Settoon, R. P., \& Henagan, S. C. (2005). A relational perspective on turnover: Examining structural, attitudinal, and behavioral predictors. Academy of Management Journal, 48(4), 607-618. https://doi.org/10.5465/amj.2005.17843941

Neog, B. B., \& Barua, M. (2014). Factors influencing employee's job satisfaction: An empirical study among employees of automobile service workshops in Assam. The SIJ Transactions on Industrial, Financial \& Business Management (IFBM), 2(7), 305-316.

Netemeyer, R. G., Boles, J. S., McKee, D. O., \& McMurrian, R. (1997). An investigation into the antecedents of organizational citizenship behaviors in a personal selling context. The Journal of Marketing, 85-98. https://doi.org/10.1177/002224299706100306

Newcomb, T. M. (1961). The acquaintance process. New York: Holt, Rinehart, \& Winston. https://doi.org/10.1037/13156-000

Nunnally, J. (1978). Psychometric Methods. New York: McGraw-Hill.

Osman, N., Purwana, D., \& Saptono, A. (2017). Do performance appraisal, compensation nd job satisfaction influence employees' loyalty of generation Y?. Journal of Business and Behavioural Entrepreneurship, 1(1), 35-49. https://doi.org/10.21009/JOBBE.001.1.04

Pervin, L. A. (1992). Transversing the individual- environment landscape: A personal odyssey. In W. B. Walsh, K. H. Craik, \& R. H. Price (Eds.), Person - environment psychology: Models and perspective (pp. 71-87). Hillsdale, NJ: Erlbaum.

Pettit, J. D. Jr., Goris, J. R., \& Vaught, B. C. (1997). An examination of organizational communication as a moderator of the relationship between job performance and job satisfaction. The Journal of Business Communication (1973), 34(1), 81-98. https://doi.org/10.1177/002194369703400105

Piasentin, K. A., \& Chapman, D. S. (2007). Perceived similarity and complementarity as predictors of subjective person-organization fit. Journal of Occupational and Organizational Psychology, 80(2), 341-354. https://doi.org/10.1348/096317906X115453

Price, J. L. (1997). Handbook of organizational measurement. International Journal of Manpower, 18(4-6), 303-558. https://doi.org/10.1108/01437729710182260

Ranz, J., Stueve, A., \& McQuistion, H. L. (2001). The role of the psychiatrist: job satisfaction of medical directors and staff psychiatrists. Community Mental Health Journal, 37(6), 525-539. https://doi.org/10.1023/A:1017582230384 
Redelinghuys, K., \& Botha, E. (2016). Person-environment fit, job satisfaction and intentions to leave: The moderating effect of leader empowering behaviour. Journal of Psychology in Africa, 26(1), 11-21. https://doi.org/10.1080/14330237.2015.1101273

Rounds, J. B., Dawis, R. V., \& Lofquist, L. H. (1987). Measurement of person - environment fit and prediction of satisfaction in the theory of work adjustment. Journal of Vocational Behavior, 31, 297-318. https://doi.org/10.1016/0001-8791(87)90045-5

Schneider, B., Kristof-Brown, A., Goldstein, H. W., \& Smith, D. B. (1997). What is this thing called fit? In N. Anderson \& P. Herriot (Eds.), International handbook of selection and assessment (pp. 393-412). London: Wiley.

Silva, N. D., Hutcheson, J., \& Wahl, G. D. (2010). Organizational strategy and employee outcomes: A personorganization fit perspective. The Journal of Psychology, 144(2), 145-161. https://doi.org/10.1080/00223980903472185

Smith. A, Oczkowski, E., \& Smith, C. S. (2008).To Have and to Hold: Retaining and Utilising Skilled People. A National Vocational Education and Training Research and Evaluation Program Report. National Centre for Vocational Education Research Ltd. PO Box 8288, Stational Arcade, Adelaide, SA 5000, Australia.

Son, S., Kim, D. Y., \& Kim, M. (2014). How perceived interpersonal justice relates to job burnout and intention to leave: The role of leader-member exchange and cognition-based trust in leaders. Asian Journal of Social Psychology, 17(1), 12-24. https://doi.org/10.1111/ajsp.12038

Spence, J. W. (1978). A case study analysis of organizational communication effectiveness between user-managers and information service department personnel. Doctoral dissertation, Texas Tech University.

Su, R., Murdock, C. D., \& Rounds, J. (2015). Person-environment fit. APA Handbook of Career Intervention, 1, 81-98. https://doi.org/10.1037/14438-005

Swann, W. B., Jr. (1987). Identity negotiation: Where two roads meet. Journal of Personality and Social Psychology, 53, 1038-1051. https://doi.org/10.1037/0022-3514.53.6.1038

Swann, W. B., Jr., Stein-Seroussi, A., \& Giesler, B. R. (1992). Why people self-verify. Journal of Personality and Social Psychology, 62, 392-401. https://doi.org/10.1037/0022-3514.62.3.392

Thomas, G. F., Zolin, R., \& Hartman, J. L. (2009). The central role of communication in developing trust and its effect on employee involvement. The Journal of Business Communication, 46(3), 287-310. https://doi.org/10.1177/0021943609333522

Tooksoon, H. M. P. (2011). Conceptual framework on the relationship between human resource management practices, job satisfaction, and turnover. Journal of Economics and Behavioral Studies, 2(2), 41-49.

Tyagi, R., \& Gupta, M. (2005). Person-organisation fit: Practices and outcomes. Indian Journal of Industrial Relations, 64-78.

Umrani, W. A., Mahmood, R., \& Ahmed, U. (2016). Unveiling the direct effect of corporate entrepreneurship's dimensions on the business performance: a case of big five banks in Pakistan. Studies in Business and Economics, 11(1), 181-195. https://doi.org/10.1515/sbe-2016-0015

Vafa, S., Sappington, K., \& Coombs-Richardson, R. (2018). Using Augmented Reality to Increase Interaction in Online Courses. International Journal of Educational Technology and Learning, 3(2), 65-68. https://doi.org/10.20448/2003.32.65.68

Van Saane, N., Sluiter, J. K., Verbeek, J. H. A. M., \& Frings-Dresen, M. H. W. (2003). Reliability and validity of instruments measuring job satisfaction-a systematic review. Occupational Medicine, 53(3), 191-200.

Van Vianen, A. E. (2018). Person-environment fit: A review of its basic tenets. Annual Review of Organizational Psychology and Organizational Behavior, 5, 75-101. https://doi.org/10.1146/annurev-orgpsych-032117-104702

Walandari, M., \& Burgess, J. (2011). The linkage between trust, communication openness in the workplace, and employees' job satisfaction: An Indonesian case study. Employment Relations Record, 11(2), 56-74.

Zhang, J. C., Ling, W. Q., Zhang, Z. Y., \& Xie, J. (2015). Organizational commitment, work engagement, person-supervisor fit, and turnover intention: A total effect moderation model. Social Behavior and Personality: An International Journal, 43(10), 1657-1666. https://doi.org/10.2224/sbp.2015.43.10.1657 